\title{
Does oyster size matter for modelling trace metal bioaccumulation?
}

Richards, R.G ${ }^{1,2}$, and M. Chaloupka ${ }^{3}$

\footnotetext{
${ }^{1}$ Division of Chemical Engineering, Department of Engineering, University of Queensland, St Lucia, Queensland 4067, Australia

${ }^{2}$ CRC for Coastal Zone Estuary \& Waterway Management, Indooroopilly, Queensland 4068, Australia

${ }^{3}$ Ecological Modelling Services Pty Ltd, PO Box 6150, University of Queensland , St Lucia, Queensland 4067, Australia
} 


\begin{abstract}
The aim of this study was assessing whether trace metal bioaccumulation models for oysters need to account for the effect of size-structured demography. To achieve this, we used a Bayesian generalised additive mixed modelling (BGAMM) approach. This nonparametric regression approach allowed us to estimate potentially nonlinear size effects of the oysters as well as random and structured spatial effects. Native oysters were collected from ten locations around the shoreline of Moreton Bay, a subtropical estuary in southeast Queensland, Australia. The soft-tissue of these sampled oysters were weighed (dry weight basis) and then analysed for $\mathrm{Al}, \mathrm{Cu}, \mathrm{Fe}, \mathrm{Mg}, \mathrm{Mn}$ and $\mathrm{Zn}$. Of the six trace metals analysed, only Mg was found to have a significant (negative) effect of soft-tissue mass. The correlated spatial effects for $\mathrm{Cu}, \mathrm{Mn}$ and $\mathrm{Zn}$ indicated that the source of these trace metals in the oysters was from anthropogenic inputs while the correlated spatial effects for $\mathrm{Al}$ and $\mathrm{Mg}$ indicated natural inputs. The correlated spatial effect for Fe was characterised by 'hotspot' concentrations in regions of Moreton Bay where algal blooms have previously occurred and consequently oysters might be useful as an indicator of algal blooms in the Bay. Overall, the absence of an observed size effect for five of the six trace metals indicates that bioaccumulation models do not necessarily need to account for size-structured demography therefore enabling simpler models to be used.
\end{abstract}


Keywords:

Metal, bioaccumulation, oysters, spatial variation, Bayesian GAMM 


\section{INTRODUCTION}

Native oysters are widely used to monitor water quality and assess coastal ecosystem health (Brown and McPherson, 1992; Hayes et al., 1998; Lin and Hsieh, 1999) and their application as 'biomonitors' or 'sentinels of the environment' has previously been well described (Phillips 1980; Phillips and Segar, 1986; Rainbow 1995). Much of their utility arises from their ability to provide an easily measurable and time-integrated indication of contaminants. However, it is often difficult to sample oysters of uniform size both within and across sampling sites (Robinson et al., 2005) and this variability has often (Mackay et al., 1975; Phillips 1980; Frew et al., 1989; Hayes et al., 1998) but not always (Robinson et al., 2005) been a significant factor in the trace metal bioaccumulation patterns that are observed. An implication of this potential size effect is whether oyster bioaccumulation models actually need to account for size-structured demography or whether simpler models that ignore size effects can be used.

In this study, we assess the effect of oyster size on trace metal bioaccumulation using a Bayesian generalised additive mixed modelling approach. This approach allows correlated and uncorrelated spatial effects to be considered simultaneously. Our analysis was carried out using native oysters collected from the intertidal zone of Moreton Bay, which is a large subtropical coastal estuary located in southeastern Queensland, Australia. This analysis provides a basis for developing a better understanding of the effects of variable oyster size and spatial patterns on trace element bioaccumulation in oysters. 


\section{MATERIALS AND METHODS}

\section{Sampling and laboratory analysis}

The study site of Moreton Bay (153 $12^{\prime}$ E, $27^{\circ} 18^{\prime}$ S) is a wave dominated semi-enclosed embayment located in southeast Queensland, Australia (Fig. 1). The western catchment is dominated by grazing and forestry (Capelin et al., 1998) and also features the Queensland state capital city of Brisbane (population 838,000). The eastern catchment is dominated by the sparsely populated Moreton and North Stradbroke Islands.

The selection of native oyster sampling locations was guided by the desire to provide a broad coverage of the shoreline around Moreton Bay. Six adult oysters were sampled from the intertidal zone at ten locations in Moreton Bay during a one-off survey in July 2001 (Fig. 1). Robinson et al., (2005) found that six was the minimum number of samples needed to estimate the mean trace metal concentration for a population of native oysters. Each sampled oyster was carefully removed from local stratum, cleaned in the local seawater, placed in a snap-lock freezer bag, labelled and transferred to a cooler containing ice at the point of collection.

The soft-tissue of the oysters were analysed for $\mathrm{Al}, \mathrm{Cu}, \mathrm{Fe}, \mathrm{Mg}, \mathrm{Mn}$ and $\mathrm{Zn}$ and all concentrations reported on dry weight basis. Oysters were shucked using a stainless steel oyster-shucking knife and the soft-tissue transferred to individual sterile containers. Oysters were dried, weighed, digested with $0.5 \mathrm{M}$ redistilled perchloric-nitric acid and then analysed using Inductively Coupled Plasma - Atomic Emission Spectroscopy. 


\section{Bayesian regression model}

A generalised additive mixed modelling (GAMM) approach was used to explore the effect of size on the soft-tissue concentrations of the six trace metals ( $\mathrm{Al}, \mathrm{Cu}, \mathrm{Fe}, \mathrm{Mg}, \mathrm{Mn}$ and $\mathrm{Zn}$ ) in the sampled oysters. The GAMM regression models were fitted in a Bayesian inference framework using Markov chain Monte Carlo (MCMC) simulation techniques implemented in the software program Bayes X (Brezger et al., 2005). Bayesian modelling via MCMC simulations is an increasingly used approach for simultaneous estimation of fixed, nonparametric (or nonlinear) and random or structured spatial effects (Fahrmeir and Lang, 2001; Lang and Sunder, 2003; Brezger et al., 2005). The trace metal data generated from the shoreline sampling of oysters were assessed for both correlated (structured) and uncorrelated (random) spatial effects.

All unknown model parameters, including the spatial covariates, are assumed in Bayesian modelling to be random variables and therefore prior distributions need to be specified (Fahrmeir and Lang, 2001). Second-order random walk smoothness priors (Fahrmeir and Lang, 2001; Lang and Sunder, 2003) were used to assess the six trace metals against the soft tissue weight of the oysters. Two-dimensional P-spline surface smoothers (Lang and Sunder, 2003; Augustin et al., 2007) based on the geographical coordinates (latitude and longitude) of each sampling site were used for the structured spatial effects. It was assumed that the site-specific parameters (random spatial effect) were independent gaussian with a common variance (Lang and Sunder, 2003). These are all common priors used in nonparametric Bayesian regression modelling (Lang and Sunder, 2003; Augustin et al., 2007). 
Model selection was based on the deviance information criterion (DIC) approach proposed for Bayesian statistical models where the best-fit model is indicated by the lowest DIC (Speilgelhalter et al., 2002). The posterior distribution of the parameter effects for all models was sampled from 50,000 MCMC iterations following an initial burn-in period of 2000 iterations (Brezger et al., 2005). Inference concerning the effects of oyster size was based on the posterior distribution, which was then summarised using the posterior mean, standard deviation, median (50\% quantile), and 95\% credible intervals based on the posterior $2.5 \%$ and $97.5 \%$ quantiles. If the $95 \%$ credible region for a trace metal could not be fitted with a zero gradient slope then this indicated a significant relationship (see Kneib 2006 p. 790). Conversely if a zero gradient slope could be fitted then this indicated no significant relationship.

\section{RESULTS AND DISCUSSION}

The range of soft-tissue masses for the individual oysters sampled from the shoreline of Moreton Bay is presented in Fig. 2 and shows that this ranged from 0.1 to $3.3 \mathrm{~g}$. The mean soft-tissue trace metal concentrations measured at the ten sampling locations are summarised in Table 1 and this data is characterised by considerable within-site and inter-site variation as indicated by the large coefficients of variance (Table 1).

The evaluation of the best-fit model based on the DIC is presented in Table 2. Spiegelhalter et al., (2002) indicate that a change of 2 or more in DIC is considered an important difference between models. Given this ‘rule of thumb’ measure, size effects 
(Model 2) were apparent for $\mathrm{Al}, \mathrm{Cu}$ and $\mathrm{Mg}$ but not for $\mathrm{Fe}, \mathrm{Mn}$ and $\mathrm{Zn}$. Furthermore a random spatial effect (Model 3) was only apparent for Zn (Table 2). Overall, use of DIC suggested that neither size nor random spatial effects were needed in the model. However, a review of the plots in Fig. 3 shows that while the 95\% credible regions for $\mathrm{Al}, \mathrm{Cu}, \mathrm{Fe}, \mathrm{Mn}$ and $\mathrm{Zn}$ can all be fitted with zero slopes indicating no significant relationship between oyster soft-tissue mass and trace metal concentration, there was a significant (negative) effect of size on Mg concentration. While DIC has been shown to be an effective rapid screening process of model selection (Spiegelhalter et al., 2002), it appears that in this case the importance of a size effect on trace metal concentration is better evaluated from the nonparametric plots. Conversely, other emerging techniques for evaluating Bayesian models could be used in place of DIC (Aitkin et al., 2005).

Robinson et al., (2005) also observed no significant correlation between soft-tissue mass and trace metal concentration for oysters. However, Mackay et al., (1975) found that trace metal concentration in oysters decreased as soft-tissue mass increased in the manner observed here for Mg. Robinson et al., (2006) suggest that oyster soft-tissue mass might not be a significant effect on trace metal concentration if the effect of age is also accounted for. However, age is not always known in native oysters making it difficult to evaluate this effect.

The estimated correlated spatial effect posterior means for each site observed for each of the soft-tissue trace metals (Fig. 4) were processed to aid visual presentation and interpretation using bicubic interpolation for irregularly spaced data (Akima 1996), which 
was implemented using the akima package in R (Ihaka and Gentleman, 1996). There was pronounced west-east (high-low) gradients for Cu (Fig. 4b), Mn (Fig. 4e) and Zn (Fig. 4f) that appear to reflect the proximity of the sampled oysters to populated catchment areas of Moreton Bay. The western catchment area of the Bay is heavily populated and dominated by Queenslands capital, Brisbane City, while the eastern catchment of Moreton Island and North Stradbroke Island is sparsely populated. Conversely, an opposite east-west (high-low) gradient was observed for Al (Fig. 4a) and Mg (Fig. 4d) suggesting that the distribution of these metals is a result of natural inputs rather than anthropogenic inputs. Finally, Fe (Fig. 4c) was characterised by 'hotspot' concentrations at Deception Bay to the north and Redland Bay to the south, reflecting the naturally high levels of iron that occur in these regions (Cox and Preda, 2005). Interestingly, algal blooms in both of these regions have been linked to elevated Fe levels (Dennison et al., 1999) and therefore measuring Fe concentrations in oysters might be useful as an indicator of algal blooms in Moreton Bay.

The absence of an observed size effect for five of the six trace metals indicates that oyster bioaccumulation models do not need to include size-structured demography when modelling Al, Cu, Fe, Mn and Zn concentrations. Rather, simpler bioaccumulation models that do not account for size effects can be used in these instances. Models that do account for size effects such as those using a dynamic energetic budget framework (Kooijman and van Haren, 1990) can be difficult to parameterise because of increased complexity. Therefore the use of simpler models is advantageous because of the reduced parameter requirements. 


\section{REFERENCES}

Aitkin M, Boys RJ, Chadwick T. Bayesian point null hypothesis testing via the posterior likelihood ratio. Stat Comput 2005;15:217-230.

Akima H. Algorithm 761; scattered-data surface fitting that has the accuracy of a cubic polynomial, ACM. T Math Sc1996;22:362-371.

Augustin NH, Lang S, Musio M, von Wilpert K. A spatial model for the needle losses of pine trees in the forests of Baden-Württemberg: An application of Bayesian structured additive regression. Appl Stat 2007;56:29-50.

Brezger A, Kneib T, Lang S. BayesX: Analyzing Bayesian Structured Additive Regression Models. J Statist Software 2005;14.

Brown KR, McPherson RG. Concentrations of Copper, Zinc and Lead in the Sydney Rock Oyster, Saccostrea commercialis (Iredale and Roughley) from the Georges River, New South Wales. Sci Total Environ 1992;126:27-33.

Capelin, M, Kohn P, Hoffenberg P. Land Use, Land Cover and Land Degradation in the Catchment of Moreton Bay. Moreton Bay and Catchment. I. R. Tibbetts, N. J. Hall and W. C. Dennison. Brisbane, School of Marine Sciences, The University of Queensland 1998:55-66.

Cox ME, Preda M. Trace Metal Distribution Within Marine and Estuarine Sediments of Western Moreton Bay, Queensland, Australia: Relation to Land Use and Setting. Geogr Res 2005;43:173-193.

Dennison WC, O’Neil JM, Duffy EJ, Oliver PE, Shaw GR. Blooms of the cyanobacterium Lyngbya majuscula in coastal waters of Queensland, Australia. Bull Inst Oceanogr 1999;19:501-506. 
Fahrmeir L, Lang S. Bayesian Inference for Generalized Additive Mixed Models based on Markov Random Field Priors. Appl Stat 2001;50:201-220.

Frew RD, Hunter KA, Beyer R. Cadmium in the dredge oyster Ostrea lutaria Dependence on age, body weight and distribution in internal organs. Mar Pollut Bull 1989;20:463-464.

Hayes WJ, Anderson IJ, Gaffoor MZ, Hurtado J. Trace Metals in Oysters and Sediments of Botany Bay, Sydney. The Science of the Total Environment 1998;212:39-47.

Ihaka R, Gentleman R. R: a language for data analysis and graphics. J Comput Graph Stat 1996;5:299-314.

Kneib T. Mixed model-based inference in geoadditive hazard regression for intervalcensored survival times. Comput Stat Data An 2006;51:777-792.

Kooijman, SALM, van Haren RJF. Animal energy budgets affect the kinetics of xenobiotics. Chemosphere 1990;21:681-693.

Lang S, Sunder M, 2003. Nonparametric regression with BayesX: a flexible estimation of trends in human physical stature in 19th century America. Econ Human Biol 2003;50:201-220.

Lin S, Hsieh I-JY. Occurrences of green oysters and heavy metals contaminant levels in the Sien-San area, Taiwan. Mar Pollut Bull 1999;38:960-965.

Mackay NJ, Williams RJ, Kacprzac JL, Kazacos MN, Collins AJ, Auty EH. Heavy Metals in Cultivated Oysters (Crassostrea commercialis = Saccostrea cucullata) from the Estuaries of New South Wales. Aust J Mar Freshwater Res 1975;26:3146. 
Phillips DJH. Quantitative Aquatice Biological Indicators. London, Applied Science Publishers 1980.

Phillips DJH, Segar DA. Use of bio-indicators in monitoring conservative contaminants: programme design imperatives. Mar Pollut Bull 1986;17:10-17.

Rainbow PS. Biomonitoring of Heavy Metal Availability in the Marine Environment. Mar Pollut Bull 1995;31:183-192.

Robinson, WA, Maher WA, Krikowa F, Nell JA, Hand R. The use of the oyster Saccostrea glomerata as a biomonitor of trace metal contamination: Intra-sample, local scale and temporal variability and its implication for biomonitoring. J Environ Monitoring 2005;7:208-223.

Spiegelhalter DJ, Best NG, Carlin BP, van der Linde A. Bayesian measures of model complexity and fit. J Roy Statist Soc B 2002;64:583-639. 
Table 1. Mean trace element concentrations measured in the soft tissue (dry weight basis) of the collected oysters. Values in parentheses represent coefficient of variation $(\mathrm{cv}=$ [standard deviation/mean] x 100).

\begin{tabular}{|c|c|c|c|c|c|c|c|c|c|c|}
\hline Metal & Wynnum & Shorncliffe & $\begin{array}{c}\text { Wellington } \\
\text { Point }\end{array}$ & Beachmere & $\begin{array}{c}\text { Redland } \\
\text { Bay }\end{array}$ & Cleveland & $\begin{array}{c}\text { Cabbage } \\
\text { Tree Pt }\end{array}$ & Myora & $\begin{array}{l}\text { Blue } \\
\text { Hole }\end{array}$ & Dunwich \\
\hline Al & $\begin{array}{c}31 \\
(10 \%)\end{array}$ & $\begin{array}{c}32 \\
(146 \%)\end{array}$ & $\begin{array}{c}51 \\
(58 \%)\end{array}$ & $\begin{array}{c}107 \\
(88 \%)\end{array}$ & $\begin{array}{c}65 \\
(71 \%)\end{array}$ & $\begin{array}{c}71 \\
(37 \%)\end{array}$ & $\begin{array}{c}70 \\
(78 \%)\end{array}$ & $\begin{array}{c}267 \\
(60 \%)\end{array}$ & $\begin{array}{c}36 \\
(82 \%)\end{array}$ & $\begin{array}{c}136 \\
(55 \%)\end{array}$ \\
\hline $\mathrm{Cu}$ & $\begin{array}{c}681 \\
(49 \%)\end{array}$ & $\begin{array}{c}169 \\
(62 \%)\end{array}$ & $\begin{array}{l}227 \\
(5 \%)\end{array}$ & $\begin{array}{c}203 \\
(18 \%)\end{array}$ & $\begin{array}{c}592 \\
(11 \%)\end{array}$ & $\begin{array}{c}438 \\
(16 \%)\end{array}$ & $\begin{array}{l}274 \\
(48 \%)\end{array}$ & $\begin{array}{c}72 \\
(29 \%)\end{array}$ & $\begin{array}{c}42 \\
(45 \%)\end{array}$ & $\begin{array}{c}111 \\
(26 \%)\end{array}$ \\
\hline $\mathbf{F e}$ & $\begin{array}{c}408 \\
(67 \%)\end{array}$ & $\begin{array}{c}350 \\
(115 \%)\end{array}$ & $\begin{array}{c}498 \\
(94 \%)\end{array}$ & $\begin{array}{r}2354 \\
(81 \%)\end{array}$ & $\begin{array}{c}2599 \\
(127 \%)\end{array}$ & $\begin{array}{c}690 \\
(39 \%)\end{array}$ & $\begin{array}{c}219 \\
(55 \%)\end{array}$ & $\begin{array}{c}187 \\
(50 \%)\end{array}$ & $\begin{array}{c}56 \\
(54 \%)\end{array}$ & $\begin{array}{c}146 \\
(22 \%)\end{array}$ \\
\hline Mg & $\begin{array}{c}2371 \\
(19 \%)\end{array}$ & $\begin{array}{r}3188 \\
(46 \%)\end{array}$ & $\begin{array}{r}2826 \\
(15 \%)\end{array}$ & $\begin{array}{l}3367 \\
(13 \%)\end{array}$ & $\begin{array}{c}3140 \\
(26 \%)\end{array}$ & $\begin{array}{r}5137 \\
(30 \%)\end{array}$ & $\begin{array}{c}3643 \\
(23 \%)\end{array}$ & $\begin{array}{c}4390 \\
(28 \%)\end{array}$ & $\begin{array}{l}3454 \\
(32 \%)\end{array}$ & $\begin{array}{c}5110 \\
(43 \%)\end{array}$ \\
\hline Mn & $\begin{array}{c}11.1 \\
(20 \%)\end{array}$ & $\begin{array}{c}10.8 \\
(66 \%)\end{array}$ & $\begin{array}{c}18.9 \\
(38 \%)\end{array}$ & $\begin{array}{c}20.2 \\
(48 \%)\end{array}$ & $\begin{array}{c}17.1 \\
(59 \%)\end{array}$ & $\begin{array}{c}11.9 \\
(48 \%)\end{array}$ & $\begin{array}{c}13.3 \\
(40 \%)\end{array}$ & $\begin{array}{c}5.3 \\
(46 \%)\end{array}$ & $\begin{array}{c}3.8 \\
(39 \%)\end{array}$ & $\begin{array}{c}5.8 \\
(31 \%)\end{array}$ \\
\hline Zn & $\begin{array}{r}2459 \\
(36 \%)\end{array}$ & $\begin{array}{c}1360 \\
(26 \%)\end{array}$ & $\begin{array}{c}879 \\
(20 \%)\end{array}$ & $\begin{array}{c}1024 \\
(22 \%)\end{array}$ & $\begin{array}{c}2360 \\
(19 \%)\end{array}$ & $\begin{array}{l}1938 \\
(8 \%)\end{array}$ & $\begin{array}{c}1999 \\
(30 \%)\end{array}$ & $\begin{array}{c}875 \\
(32 \%)\end{array}$ & $\begin{array}{c}562 \\
(44 \%)\end{array}$ & $\begin{array}{c}1271 \\
(35 \%)\end{array}$ \\
\hline
\end{tabular}


Table 2. Summary of model selection results for Al, Cu, Fe, Mg, Mn and Zn. The best-fit model is determined by the lowest deviance information criterion (DIC) value, which are shown in bold. Model 1 = Global Model; Model 2 = Global Model - size effect; Model 3 = Global Model - size effect - random spatial effect.

\begin{tabular}{cccc}
\hline Trace Metal & \multicolumn{3}{c}{ DIC } \\
\cline { 2 - 4 } & Model 1 & Model 2 & Model 3 \\
\hline $\mathrm{Al}$ & 73.22 & 69.92 & 71.03 \\
$\mathrm{Cu}$ & 72.96 & 70.37 & 67.98 \\
$\mathrm{Fe}$ & 69.21 & 68.53 & 70.34 \\
$\mathrm{Mg}$ & 72.95 & 70.43 & 69.13 \\
$\mathrm{Mn}$ & 68.58 & 68.73 & 70.22 \\
$\mathrm{Zn}$ & 72.38 & 70.78 & \\
\hline
\end{tabular}




\section{Figures}

Fig. 1. Map of Moreton Bay indicating the oyster sampling sites.

Fig. 2. Range of soft-tissue mass (dry weight basis) measured in the sampled oysters.

Fig. 3. Estimated non-parametric functions of oyster soft-tissue weight (dry weight basis)

for $\mathrm{Al}, \mathrm{Cu}, \mathrm{Fe}, \mathrm{Mg}, \mathrm{Mn}$ and $\mathrm{Zn}$. Posterior means within the 95\% credible regions are shown.

Fig. 4. Correlated spatial effects of trace metal concentrations using two-dimensional pspline surface smoothers. (a.) Al, (b.) Cu, (c.) Fe, (d.) Mg, (e.) Mn and (f.) Zn. 


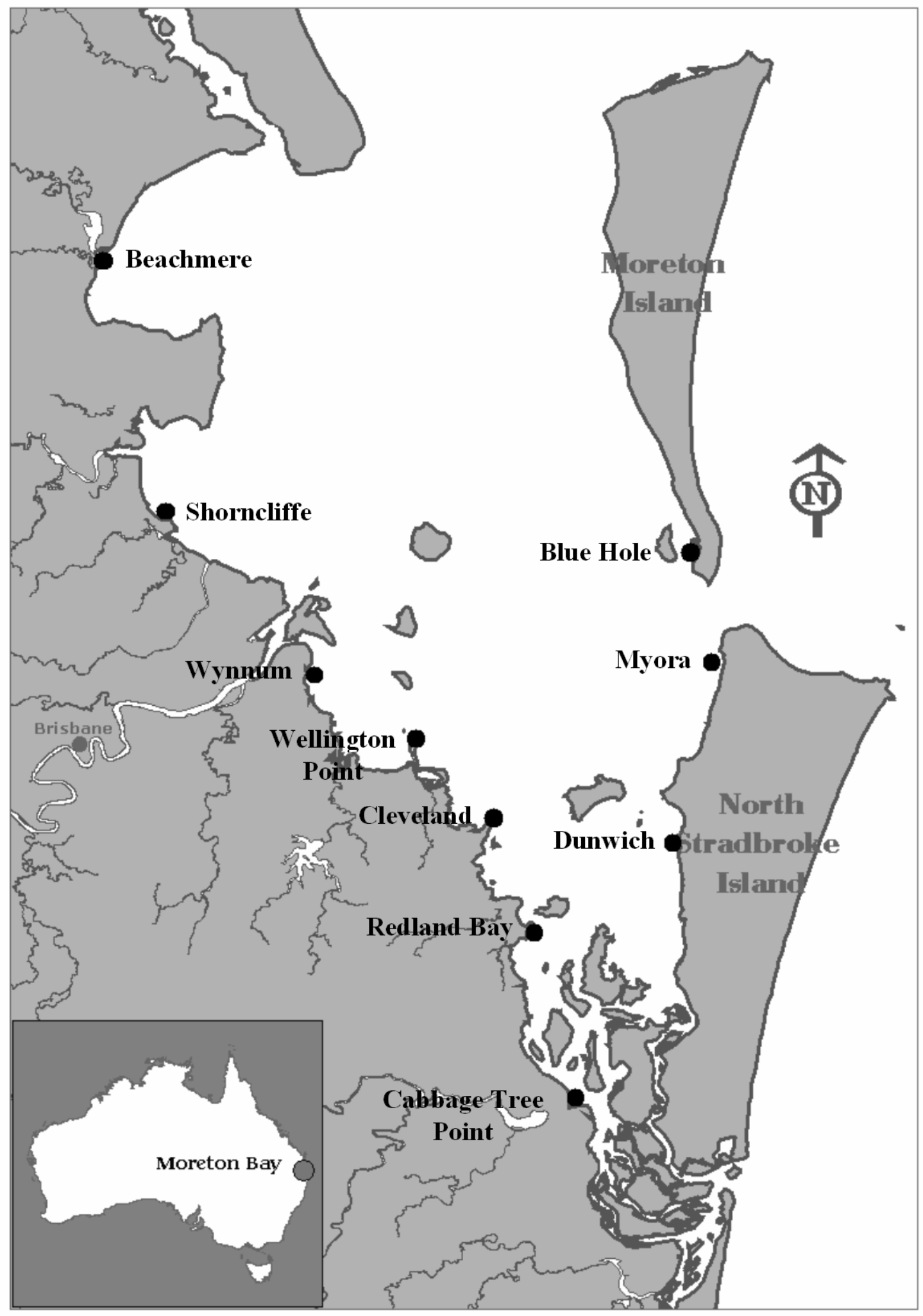




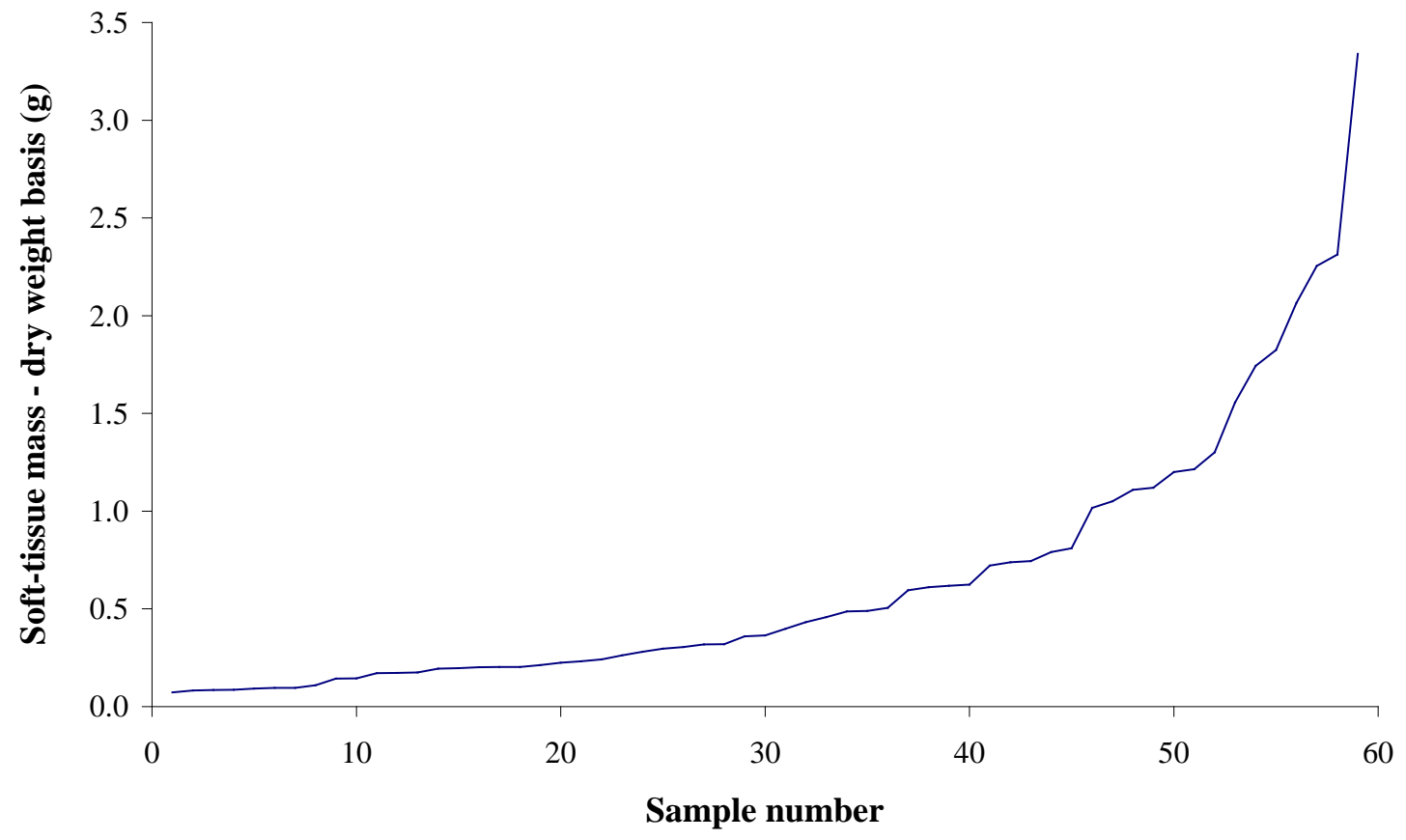


A

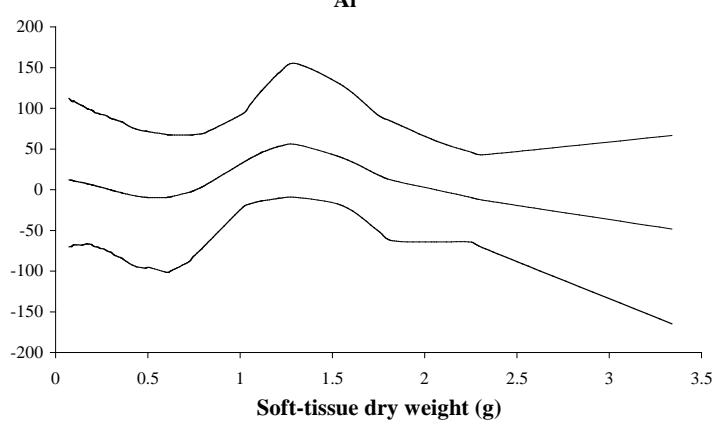

Fe

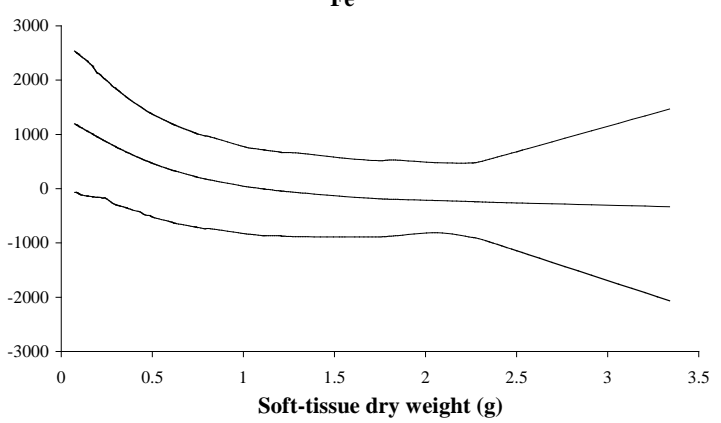

Mn

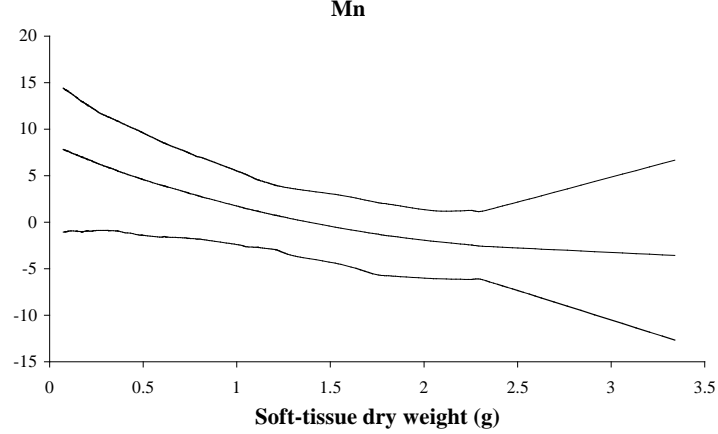

Cu

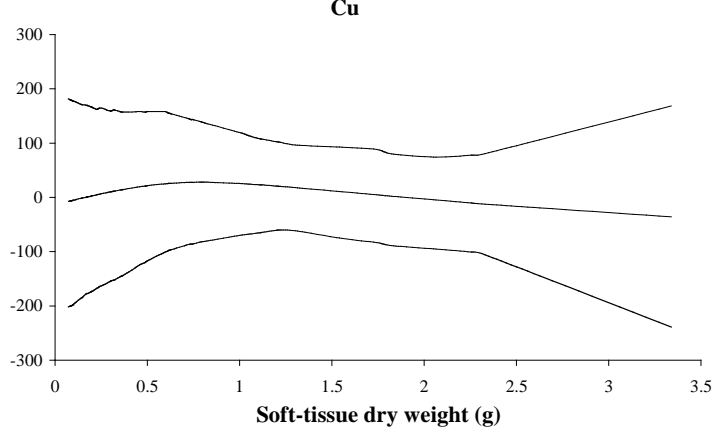

Mg

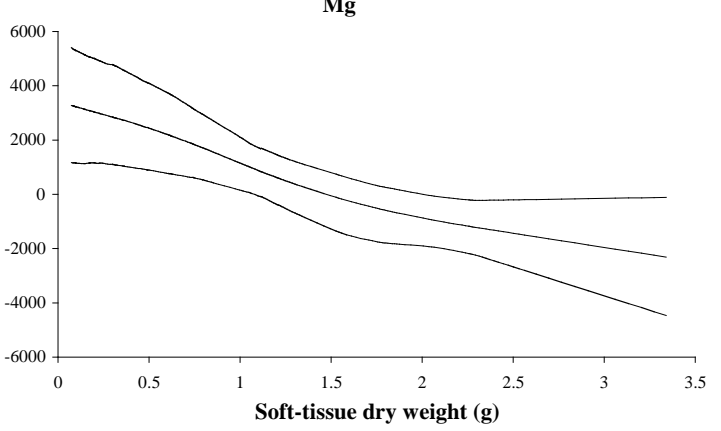

Zn

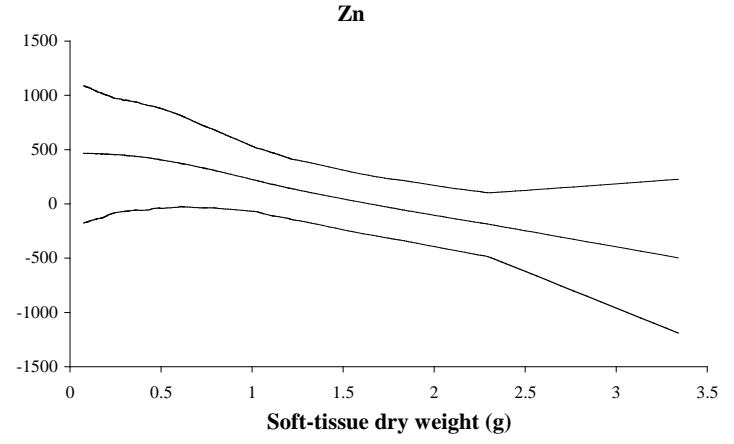



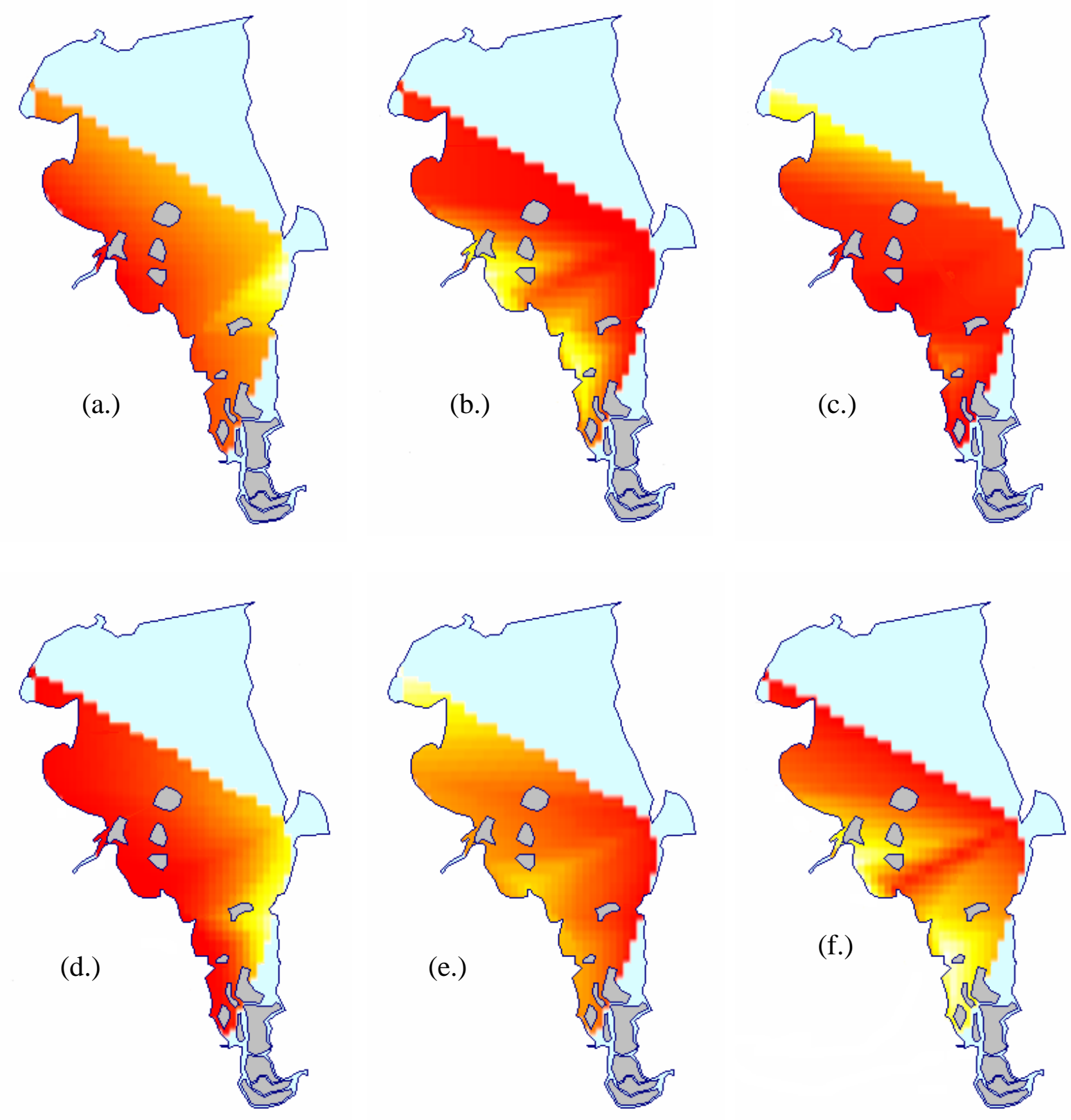

SCALE

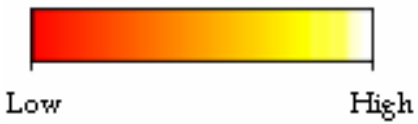

